\title{
THE IMPACT OF NON-UNIONISED PARTICIPATION PLATFORMS ON EMPLOYEE PRODUCTIVITY IN THE SOUTH AFRICAN WORKPLACE
}

\author{
Gerhardus van Zyl \\ University of Johannesburg \\ hardusvz@uj.ac.za
}

Received: September 2015

Accepted: January 2016

\begin{abstract}
The aim of the article is to determine the impact that different participation platforms might have on employee productivity levels of the lower-skilled non-unionised employee segment of the South African workplace. A firm-based dynamic log-linear Cobb-Douglas production function model is used as it allows for the incorporation of the dynamic characteristics of the non-unionised employee segment of the South African workplace. The main conclusions of the study are that, i) the positive productivity spill-over effects of a formal committee participation platform in the lower-skilled nonunionised employee segment of the South African workplace are superior to non-committee participation platforms and, ii) a more dispersed racial participation rate, greater gender spread and a dynamic age spread for non-unionised employees are important contributing factors towards the enhancement of higher productivity levels for lower-skilled non-unionised employee participation platforms.
\end{abstract}

Keywords

Non-unionised employee segment, formal committee participation platform, non-committee participation platform, non-unionised employee dimensional productivity relationships, non-unionised employee attributes, firm-based characteristics

Prof $\mathbf{G}$ van Zyl is professor in the Department of Economics and Econometrics, University of Johannesburg, South Africa. 


\section{INTRODUCTION}

The aim of the article is to determine the impact that different participation platforms might have on employee productivity levels of the lower-skilled non-unionised employee segment of the South African workplace. In the estimation process of the non-unionised employee- employee productivity relation for different participation platforms the study considers:

i. the impact of firm-specific characteristics;

ii. the impact of employee-diversity attributes;

iii. the impact of industry differences; and

iv. the impact of different non-unionised employee sizes.

The study specifically incorporated individual firm-based data in the estimation process. The manufacturing and the construction industries of Gauteng Province are used as case studies.

The article forms part of the ongoing general debate on employee productivity in the South African workplace. Motivation for this particular study emanates largely from the published results of the Van Zyl (2013) paper that deals with the age-skill employee productivity debate and the Van Zyl (2015) paper that deals with incentive-based employee productivity gains. Both these papers conclude that low employee productivity levels are prevalent in the relatively unionised lowerskilled employee segment of the South African workplace. Of particular interest for this study are the results of the Van Zyl (2015) paper in which it is concluded that the non-financial incentivebased (such as employee participation platforms, flexible job design and job rotation) productivity gains in the more unionised lower-skilled employee segment are relatively small compared to the higher-skilled segment. Based on the empirical results of both the Van Zyl (2013) and Van Zyl (2015) papers this particular article focusses specifically on the employee productivity impact of the non-financial employee participation dimension of the lower-skilled non-unionised employee segment.

Literature on the employee productivity impacts of non-unionised employee participation platforms in developing economies is non-existent, while published literature for developed economies clearly indicates higher positive employee productivity levels (Addison, Schank, Schnabel \& Wagner, 2004; Frick \& Moeller, 2003; Huebler \& Jirjahn, 2003; Mueller, 2009). In order to expand the debate on employee productivity in South Africa it is deemed important to determine whether greater levels of non-unionised employee participation in different decision-making platforms (specifically in the lower-skilled segment) could enhance non-unionised employee productivity levels. In the estimation process the study encompasses important impactattributes such as different non-unionised employee shares, different non-unionised employee participation practices, different firm-specific characteristics, employee-diversity attributes and industry differences.

\section{LITERATURE REVIEW}

By far the majority of research results indicate a strong positive relationship between nonunionised employee participation platforms and employee productivity (Addison et al., 2004, Askildsen, Jirjahn \& Smith, 2006; Black \& Lynch, 2001; Doucouliagos \& Laroche, 2004; Peetz, 2012). Mueller (2009) argues that developed economies have experienced declining union density over the past few decades and this created a surge of alternative employee relationships (such as a 
variety of employee participation platforms) in the workplace. In this regard the study of Askildsen et al. (2006) concluded that the efficient implementation and monitoring of alternative non-unionised employee participation platforms are of the utmost importance for the successful enhancement of employee productivity levels; and the establishment of an effective legal framework to enforce the implementation of decisions taken by these non-unionised employee participation platforms is essential for the success rate of these non-unionised employee platforms. Freeman and Lazear (1995) focus on the mandatory dimension of non-unionised employee platforms (specifically works councils) as a pre-requisite for the enhancement of the productivity levels of the non-unionised employee segment. Mueller (2009) argues that effective communication between management/owners and non-unionised employees form the basis for the positive link between employee productivity and non-unionised employee participation platforms in the sense that such effective communication lines enhance the quality of managerial decision-making. In the same vein Addison et al. (2004) argues that, i) effective consultation and co-determination that flows from non-unionised employee participation platforms enable management/owners to improve the quality of decision making (especially when agreement is necessary for a particular decision to be taken and implemented) and, ii) the successful implementation of non-unionised employee platforms do result in higher productivity levels and also in lower employee turnover rates. Rogers and Streek (1995) are of the opinion that the reduction in information asymmetries between non-unionised employees and management/owners (due to the effective implementation of non-unionised employee participation platforms) form the basis for the creation of positive employee productivity spillover effects in the non-unionised employee segment.

The majority of studies (Addison et al., 2004; Askildsen et al., 2006; Frick et al., 2003; Huebler et al., 2003; Mueller 2009; Wolf \& Zwick, 2002) on the non-unionised employee participation platform - employee productivity link are in general agreement that the inclusion of the following variables in the estimation process are important: i) value added and not total sales should be used as a proxy for non-unionised employee productivity, ii) both capital (technology) and the nonunionised employee segment (in order to address endogeneity problems), iii) firm-specific attributes (such as firm size, form of ownership, magnitude of involvement in domestic and foreign markets), iv) industry differences, v) all forms of non-unionised employee participation platforms, vi) non-unionised employee-diversity attributes (age and gender) and vii) the identification of unobserved variables that would simultaneously explain employee productivity and self-selection into non-unionised employee platforms.

Mueller (2009) indicates that differences in estimated coefficients are in the main the result of the implementation of different estimation techniques. Pooled ordinary least squared (OLS) estimations provided larger employee productivity estimates while fixed-effect panel data estimates produced smaller employee productivity estimates. A plausible explanation for the larger employee productivity estimates is unobserved heterogeneity that resulted in upwardbiased OLS estimates and a plausible explanation for the smaller fixed-effect panel data employee productivity estimates is the implementation of within-firm variations in order to identify partial effects.

As previously indicated, this study considers the lower-skilled non-unionised segment of the South African workplace. The less-skilled category B occupations of the International Standard Classification (ISCO-8) are used (van Zyl, 2013). Given some distinct characteristics of the South African workplace (labour legislation, labour relations environment, the nature of employee participation practices, diversity issues such as race and gender and firm-specific attributes) compared to the dynamics of the workplace of developed economies, the estimation process for 
this particular research requires the implementation of specific control variables. The Mueller (2009) study on the employee productivity impact of non-unionised works councils in the German economy applied a dynamic representation of a log-linear Cobb-Douglas production function that includes the capital stock, the non-unionised employee component and all applicable control variables (such as non-unionised employee participation platforms, firm-based characteristics and employee-specific attributes). It was decided for the purpose of this study to use an adapted version of this dynamic log-linear Cobb-Douglas production function model, as it would allow for the incorporation of the dynamic characteristics of the non-unionised employee segment of the South African workplace.

\section{RESEARCH DESIGN}

\subsection{Research approach and method}

The research design comprises the

- identification of the different non-unionised employee participation practices, different sizes of the lower-skilled non-unionised employee segment, firm-specific attributes and employee-diversity attributes,

- specification of the estimation model that would capture the impact of the different nonunionised employee participation platforms and the dimensional relationships (sizes of the non-unionised employee segment, firm-specific and employee-specific attributes) on employee productivity,

- compilation of firm-based data sets for the proxy firms in the manufacturing and construction industries of Gauteng Province,

- estimation process and

- interpretation of the estimation results.

\subsection{Model specification}

The methodology of the adapted Mueller (2009) model as it is applied in this particular study is explained in the following few paragraphs.

$$
\ln \left(Y_{i t}\right)=\alpha \ln \left(K_{i t}\right)+\beta \ln \left(L_{i t}\right)+\lambda \ln \left(v_{i t}\right)+\gamma \ln \left(Z_{i t}\right)+\eta \ln \left(X_{i t}\right)+\sigma_{i q}
$$

where $y_{i t}$ represents value added for firm i over period $t ; \alpha$ is the parameter estimate for the capital stock of firm i over period $t$; $\lambda$ is the parameter estimate for vector $\left(v_{i t}\right)$ that includes the different non-unionised participation platforms for firm i over period $t ; \gamma$ is the parameter estimate for vector $Z_{i t}$ that includes the different non-unionised employee sizes and firm-specific attributes for firm i over period $t ; \eta$ is the parameter estimate for vector $X_{i t}$ that includes nonunionised employee-diversity attributes for firm i over period $t ; \sigma_{i t}$ is the unknown parameters for firm i over period $t$

Fixed-effect panel data estimations are done for the sample groups in both industries in terms of the impact of the different non-unionised employee participation platforms on employee productivity: taking into account the different firm-specific and employee-diversity attributes of the lower-skilled non-unionised employee segment. The dimensional relations that are specifically estimated for each industry are: 
- the size of the non-unionised employee segment - non-unionised participation platform employee productivity dimension;

- the firm-size - non-unionised employee participation platform - employee productivity dimension;

- the ownership structure - non-unionised employee participation platform - employee productivity dimension;

- the market focus of firms - non-unionised employee participation platform - employee productivity dimension;

- the employee age - non-unionised employee participation platform - employee productivity dimension;

- the gender - non-unionised employee participation platform - employee productivity dimension; and

- the racial mix - non-unionised employee participation platform - employee productivity dimension.

In order to enable a comparison of the estimated results with similar international studies the following differentiations are applied. In terms of the size of the non-unionised employee segment, three different sizes are considered, namely a non-unionised employee segment less than $10 \%$ of total employees, a non-unionised employee segment greater than $10 \%$ but less than $20 \%$ of total employees and a non-unionised employee segment greater than $20 \%$ of total employees. Two categories of non-unionised employee participation platforms are considered, namely formal committees (in whatever format) and non-committee-based platforms (for example flexible job design and job rotation inputs). In terms of the firm size two categories are used, namely bigger firms (more than 100 employees in total) and smaller firms (less than 100 employees). The differentiation in terms of firm ownership is based on two distinct categories, namely those firms that have a less than $50 \%$ family-owned control structure and firms that have a more than $50 \%$ family-owned control structure. The production focus of the firms is also considered. The distinction is made between firms with a local market focus of more than $50 \%$ of total sales and those firms with a less than $50 \%$ local market focus. The lower-skilled nonunionised employee-diversity vector considers a non-unionised employee segment, i) in which one particular race group has a more than a $60 \%$ share, ii) in which no one particular race group has a more than a $60 \%$ share, iii) of a gender distribution of less than $25 \%$ female participation, iv) of a gender distribution of a more than $25 \%$ female participation, v) of an average employee age of 35 years and younger, v) of an average employee age older than 35 but younger than 55 years of age and, vi) of an average employee age older than 55 years of age.

Fixed-effect panel data estimations are done in order to determine the impact of the lower-skill non-unionised employee participation platforms on employee productivity, namely i) estimations for the formal committee participation platform - employee productivity dimensional relationships and, ii) estimations for the non-committee participation platform employee productivity dimensional relationships. In the fixed-effect panel data estimations the impact of the dimensional relationship variables such as different sizes of the non-unionised employee segments, the applicable firm-specific attributes and employee-specific attributes are included. 


\subsection{Data collection process}

In order to capture the industry differences in the lower-skilled non-unionised employee participation platform - employee productivity relationship, the manufacturing and construction industries of Gauteng Province as proxies for industry-related differences are included, given the importance of these two industries in the gross geographical product (GGP) of the Gauteng Province and also given the availability of firm-based data.

Contact information was supplied by the Construction Education and Training Authority (CETA), Manufacturing Sector Education and Training Authority (MERSETA), Department of Labour and the Chamber of Business. Statistical validation requires a representative spread of firms in the two industries. The sample responses and the sub-sector spread within the two industries of 61 firms in the manufacturing industry and 43 firms in the construction industry are confirmed to be statistically significant.

The sample period was for the calendar years 2011-2013. For each firm in the sample group data was collected on the total size of the non-unionised employee segment of the lower-skilled category (category B jobs), value added (calculated as total employee cost to company + operating profit before depreciation), gender and the age distribution of the non-unionised segment of the lower-skilled employee category, the racial spread of the non-unionised employee segment of the lower-skilled employee category, the different kinds of employee participation practices, the number of non-unionised employees of the lower-skilled employee category per participation platform, the total number of employees, the ownership structure and total sales domestically and on export markets.

A summary of the sample statistics is listed in annexure A. In terms of the sample statistics the following can be deduced:

- The average value added, net capital stock and the number of employees are more prominent for firms in the manufacturing sector;

- There is a greater concentration of firms in the bigger firm category (more than 100 employees) and for the manufacturing industry in particular;

- There are more non-unionised employees in category B jobs for the smaller firm segment (compared to the bigger firm segment). For both firm sizes the concentration of lower-skilled non-unionised employees is more prominent in the less than $10 \%$ of total employee bracket (this is applicable to the manufacturing industry in particular);

- In terms of the two non-unionised employee participation platforms the weighted concentration index is more prominent in the formal committee category;

- For both industries $i$ ) the less than $50 \%$ family-owned ownership structure is more prominent and ii) there is a greater share of domestic sales compared to export market sales;

- In terms of the employee-diversity attributes

- there is a greater concentration (more than $60 \%$ ) of one specific race group in the nonunionised employee segment of category B jobs (it is prevalent for both industries);

- the less than $25 \%$ female participation rate in the non-unionised employee segment of the category B jobs is prominent for both industries; and

- the bigger concentration of non-unionised employees in the $35-55$ age bracket is prevalent for both industries. 


\section{THE ESTIMATION RESULTS}

TABLE 1: Fixed-effect panel data employee productivity estimates for the dimensional relationship variables of formal committee and non-committee participation platforms of the lower-skilled non-unionised employee segment

\begin{tabular}{|c|c|c|c|c|}
\hline \multirow[b]{2}{*}{ Dimensional relationship variables } & \multicolumn{2}{|c|}{ Formal committee } & \multicolumn{2}{|c|}{ Non-committee } \\
\hline & $M * *$ & $C^{* *}$ & $M * *$ & $C^{* *}$ \\
\hline \multirow[t]{2}{*}{ Non-unionised segment $<10 \%(\gamma)$} & 3.41 & 3.11 & -0.17 & -0.11 \\
\hline & $(0.78)$ & $(0.61)$ & $(0.02)$ & $(0.01)$ \\
\hline \multirow[t]{2}{*}{ Non-unionised segment $>10 \%$ but $<20 \%(\gamma)$} & 3.71 & 3.07 & -0.28 & -0.21 \\
\hline & $(0.83)$ & $(0.66)$ & $(0.03)$ & $(0.02)$ \\
\hline \multirow[t]{2}{*}{ Non-unionised segment $>20 \%(\gamma)$} & 4.14 & 3.73 & 0.35 & 0.26 \\
\hline & $(1.28)$ & $(0.71)$ & $(0.01)$ & $(0.01)$ \\
\hline \multirow[t]{2}{*}{ Firms > 100 employees $(\gamma)$} & -1.72 & -0.93 & -3.14 & -2.97 \\
\hline & $(0.64)$ & $(0.08)$ & $(0.72)$ & $(0.53)$ \\
\hline \multirow[t]{2}{*}{ Firms $<100$ employees $(\gamma)$} & 3.11 & 2.31 & 0.34 & 0.17 \\
\hline & $(0.81)$ & $(0.51)$ & $(0.02)$ & $(0.01)$ \\
\hline \multirow[t]{2}{*}{ Firms $<50 \%$ family-owned $(\gamma)$} & 1.87 & 1.12 & -0.62 & -0.51 \\
\hline & $(0.29)$ & $(0.28)$ & $(0.03)$ & $(0.02)$ \\
\hline \multirow[t]{2}{*}{ Firms $>50 \%$ family-owned $(\gamma)$} & 4.09 & 3.34 & 1.71 & 1.36 \\
\hline & $(1.02)$ & $(0.68)$ & $(0.52)$ & $(0.32)$ \\
\hline \multirow[t]{2}{*}{ Firms $>50 \%$ domestic sales $(\gamma)$} & 1.21 & 2.01 & 0.65 & 0.38 \\
\hline & $(0.15)$ & $(0.53)$ & $(0.22)$ & $(0.13)$ \\
\hline \multirow[t]{2}{*}{ Firms $<50 \%$ domestic sales $(\gamma)$} & 1.12 & 1.34 & 0.45 & 0.29 \\
\hline & $(0.11)$ & $(0.52)$ & $(0.08)$ & $(0.06)$ \\
\hline \multirow[t]{2}{*}{ One race group concentration $>60 \%(\eta)$} & -0.72 & -1.14 & -2.45 & -2.79 \\
\hline & $(0.08)$ & $(0.43)$ & $(0.98)$ & $(0.87)$ \\
\hline \multirow[t]{2}{*}{ One race group concentration $<60 \%(\eta)$} & 2.43 & 1.93 & -0.37 & -0.19 \\
\hline & $(0.61)$ & $(0.38)$ & $(0.04)$ & $(0.02)$ \\
\hline \multirow[t]{2}{*}{ Female participation < $25 \%(\eta)$} & -0.52 & -0.81 & -1.36 & -1.07 \\
\hline & $(0.03)$ & $(0.07)$ & $(0.09)$ & $(0.02)$ \\
\hline \multirow[t]{2}{*}{ Female participation > 25\% (n) } & 3.12 & 2.07 & 1.25 & 1.03 \\
\hline & $(0.45)$ & $(0.08)$ & $(0.07)$ & $(0.01)$ \\
\hline \multirow[t]{2}{*}{ Employee age 35 years and less $(\eta)$} & 0.71 & 0.03 & -1.07 & -0.97 \\
\hline & $(0.09)$ & $(0.002)$ & $(0.14)$ & $(0.02)$ \\
\hline \multirow[t]{2}{*}{ Employee age between $35-55(\eta)$} & 1.23 & 0.87 & 0.88 & 0.64 \\
\hline & $(0.78)$ & $(0.12)$ & $(0.04)$ & $(0.05)$ \\
\hline \multirow[t]{2}{*}{ Employee age older than 55 years $(\eta)$} & -1.04 & -2.71 & -2.73 & -1.98 \\
\hline & $(0.03)$ & $(0.53)$ & $(0.97)$ & $(0.54)$ \\
\hline
\end{tabular}

Source: Author's analysis

*the standard errors are significant at a $10 \%$ confidence level and are in parenthesis

$\star \star M$ is manufacturing industry and $C$ is the construction industry 
TABLE I provides a summary of the fixed-effect panel data estimation results for the different lower-skilled non-unionised employee participation platforms - employee productivity dimensional relationship variables.

The estimated non-unionised employee productivity estimates for both the formal committee and non-committee participation platforms are in general similar for the two industries, but a greater magnitude of the non-unionised employee productivity estimates is more prevalent for the manufacturing industry. Of particular interest is the fact that in general all three firm sizes of the lower-skilled non-unionised employee segment have a positive impact on employee productivity (for both employee participation platforms). Increases in the size of the non-unionised employee segment have an incremental effect on the positive non-unionised employee productivity estimates. A plausible explanation is that greater levels of lower-skilled non-unionised employee levels elevate participation rates in formal committee structures and therefore create a greater positive impact on non-unionised employee productivity levels. The estimates for the nonunionised non-committee participation platforms suggest a positive spill-over impact on nonunionised employee productivity only when the non-unionised employee segment exceeds the $20 \%$ threshold. These results are a confirmation of the Huebler et al. (2003), Mueller (2009) and the Wolf et al. (2002) studies, which highlight the superior non-unionised employee productivity spill-over effects of the formal-committee participation platform.

The non-unionised employee productivity estimates for the firm attributes vector indicate similarities (but in some cases distinct differences) between the two non-unionised employee participation platforms. Firstly, the non-unionised employee productivity estimates suggest that positive non-unionised employee productivity spill-over effects (for both the non-unionised employee formal committee and non-committee participation platforms) are only possible in the case of smaller firms, while bigger firms do not create non-unionised employee productivity spillover effects (the non-unionised employee productivity estimate is negative). The negative nonunionised employee productivity estimates are especially large for the non-committee participation platforms in the larger firm segment and the positive non-unionised employee productivity estimates for the smaller firm segment are also considerably smaller when compared to those for the formal committee platform. A plausible explanation is the suggestion of the Addison et al. (2004) study that a general deterioration of effective communication lines will occur when firms become bigger. Formal committee structures for non-unionised employee participation become less efficient, with an ultimate negative impact on non-unionised employee productivity.

Secondly, the estimated non-unionised employee productivity coefficients (for formal committee participation) are positive irrespective of the kind of ownership structure, but are more prevalent for the less dispersed ownership structure (greater than $50 \%$ family-owned control structure). For the non-committee participation platform the non-unionised employee productivity estimates are negative for the more dispersed ownership structure, and smaller positive employee productivity spill-over effects are indicated for the less dispersed ownership structure. These particular findings are a confirmation of the viewpoint of the Rogers et al. (1995) study that a less dispersed ownership structure creates a reduction in information asymmetries between management/owners and non-unionised employees when participation platforms are in place. Ultimately, positive employee productivity spill-over effects will be created.

Thirdly, positive employee productivity estimates are prevalent for both kinds of non-unionised employee participation platforms, whether the domestic sales of firms are more than $50 \%$ of total 
sales or less than $50 \%$ of total sales. The magnitude of the positive non-unionised employee productivity estimates is far less for the non-committee platforms.

The estimation results of the impact of non-unionised employee attributes on employee productivity levels for the two kinds of employee participation platforms are mixed. Firstly, the positive estimated coefficients for the two racial-mix categories of the formal committee participation platform are a further confirmation of the Van Zyl (2014) study that indicates that a smaller concentration of one specific race group (a more dispersed racial composition) in the workplace could enhance employee productivity. In the case of the non-committee participation platforms the estimation coefficients for the smaller race-concentration category are negative but less prevalent compared to the higher race-concentration category. For both the nonunionised employee participation platforms the significant negative employee productivity estimates indicate that greater levels of concentration of one particular race group in the lowerskilled non-unionised employee segment have a negative impact on non-unionised employee productivity.

Secondly, in terms of the gender composition of the non-unionised employee participation platforms the non-unionised employee productivity estimates are positive when the rate of female participation in both kinds of participation platforms increases. Given the negative nonunionised employee productivity estimates for the less than $25 \%$ female participation category it can also be argued that a less diverse gender base in both participation platforms will not create positive employee productivity spill-over effects. These results are in line with the Peetz (2012) study that indicates a positive relationship between greater levels of non-unionised gender spreads for formal works committees and employee productivity levels.

Thirdly, in terms of both kinds of non-unionised employee participation platforms non-unionised employees in the 35 to 55 years age group created the highest positive non-unionised employee productivity estimates. This is the only age group that created positive non-unionised employee productivity estimates in the case of non-committee participation platforms. For both employee participation platforms the older than 55 year age bracket produced large negative estimates. These results are in line with the Van Zyl (2013) study, which indicates very low productivity levels for the older than 55 year age bracket in the lower-skilled segment. The conclusion is that irrespective of the participation platform introduced by firms, non-unionised employees in the older than 55 year age bracket do not create positive employee productivity spill over effects.

\section{SUMMARY AND CONCLUSION}

The aim of the article is to determine the impact that different participation platforms might have on employee productivity levels of the lower-skilled non-unionised employee segment of the South African workplace.

In general, the results of this particular study indicate that there are no real industry differences when the productivity impacts of different lower-skilled non-unionised employee participation platforms are considered. The only difference is in terms of the magnitude of the non-unionised employee productivity spill-over effects (positive or negative). The study confirms the superior positive productivity spill-over effects of a formal committee participation platform in the lowerskilled non-unionised employee segment of the South African workplace (especially when a greater non-unionised employee segment is possible). In this regard the estimated results are in agreement with similar results for developed economies in which the importance of the non- 
unionised employee productivity spill-over effects of formal works committees are highlighted. In order to generate unbiased estimation results, consideration of firm-based characteristics and employee attributes is deemed important. In this regard, i) the positive productivity spill-over effects generated by non-unionised employee participation platforms (especially in the case of formal committee participation platforms) are estimated to be more prominent for smaller firms where the ownership structure is less dispersed and ii) a more dispersed racial participation rate, greater gender spread and a dynamic age spread for non-unionised employees are important contributing factors towards higher productivity levels created by lower-skilled non-unionised employee participation platforms.

Further extensions of this particular study are possible, including i) the impact of positive productivity spill-over effects of non-unionised participation platforms on the lower-skilled unionised employee segment and ii) possible geographical differences on the productivity spillover effects of non-unionised employee participation platforms.

\section{LIST OF REFERENCES}

Addison, J.T., Schnabel, C. \& Wagner, J. (2004). The course of research into the economic consequences of German Works Councils. British Journal of Industrial Relations, 42(2), pp. 255-281.

Askildsen, J.E., Jirjahn, U. \& Smith, S.C. (2006). Works Councils and environmental investment: Theory and evidence from German panel data. Journal of Economic Behavior and Organization, 60 (3), pp. 346-372.

Black, S.E. \& Lynch, M. (2001). How to compete: The impact of workplace practices and information technology on productivity. Review of Economics and Statistics, 83(3), pp. 434-445.

Blasi, J. \& Kruse, D. (2006). U.S. high performance work practice's at century's end. Industrial Relations, 45(4), pp. 547-578.

Doucouliagos, C. \& Laroche, P (2003). What do unions do to productivity? A meta-analysis. Industrial Relations, 42, pp. 650-691.

Frick, B. \& Moeller, I. (2003). Mandated Works Councils and firm performance: Labor productivity and personnel turnover in German establishments. Schmollers Jahrbuch, 3, pp. 423-454.

Freeman, R.B. \& Lazear, દ. (1995). An economic analysis of Works Councils. In J. Rogers \& W. Streeck (eds.), Works Councils: Consultation, representation and cooperation in industrial relations, pp. $27-$ 52, University of Chicago Press.

Huebler, 0. \& Jirjahn, U. (2003). Works Councils and collective bargaining in Germany: The impact on productivity and wages. Scottish Journal of Political Economy, 50(4), pp. 471-491.

Mueller, S. (2009). The productivity effect of non-union representation. Bavarian Graduate Program in Economics (BGPE). (Discussion paper no. 74).

Peetz, D. (2012). Does industrial relations policy affect productivity? Australian Bulletin of Labour, 38(4), pp. 268-292.

Rogers, J. \& Streeck, W. (1995). Works Councils: Consultation, representation and cooperation in industrial relations, Chicago, IL: University of Chicago Press. 
Van Zyl, G. (2013). The relative labour productivity contribution of different age-skill categories for a developing economy: The Gauteng province of South Africa as a case study. The South African Journal of Human Resource Management, 11(1), pp. 1-8.

Van Zyl, G. (2014). Labour productivity and employee diversity in the South African workplace. Journal of Economic \& Financial Sciences, 7(2), pp. 451-466.

Van Zyl, G. (2015). The impact of incentive schemes on employee productivity in the South African workplace. Journal of Economic \& Financial Sciences, 8(2), pp. 633-647.

Wolf, \&. \& Zwick, T. (2008). Reassessing the impact of high performance workplaces. Schmalenbacg Business Review, 60, pp. 160-181. 


\section{ANNEXURE A: Summary of the sample statistics}

\begin{tabular}{|c|c|c|}
\hline Variable & Manufacturing & Construction \\
\hline$y_{\text {it }}$ & 22.45 & 14.32 \\
\hline$K_{\text {it }}$ & 15.33 & 11.39 \\
\hline $\mathrm{L}_{\text {it }}$ & 1.088 & 1.014 \\
\hline Firms > 100 employees (bigger firms) * & 1.24 & 1.11 \\
\hline Firms $<100$ employees (smaller firms) * & 0.083 & 0.076 \\
\hline $\begin{array}{l}\text { Total non-unionised employees in category B jobs for firms > } 100 \\
\text { employees * }\end{array}$ & 0.018 & 0.015 \\
\hline $\begin{array}{l}\text { Total non-unionised employees in category B jobs for firms }<100 \\
\text { employees * }\end{array}$ & 0.15 & 0.11 \\
\hline $\begin{array}{l}\text { Total non-unionised employees in category B jobs }<10 \% \text { of total } \\
\text { employees in category B jobs for bigger firms * }\end{array}$ & 0.023 & 0.017 \\
\hline $\begin{array}{l}\text { Total non-unionised employees in category B jobs }<10 \% \text { of total } \\
\text { employees in category B jobs for smaller firms * }\end{array}$ & 0.0021 & 0.0019 \\
\hline $\begin{array}{l}\text { Total non-unionised employees in category B jobs }>10 \% \text { but }< \\
20 \% \text { of total employees in category B jobs for bigger firms * }\end{array}$ & 0.0083 & 0.0071 \\
\hline $\begin{array}{l}\text { Total non-unionised employees in category B jobs }>10 \% \text { but }< \\
20 \% \text { of total employees in category B jobs for smaller firms * }\end{array}$ & 0.0011 & 0.0010 \\
\hline $\begin{array}{l}\text { Total non-unionised employees in category B jobs }>20 \% \text { of total } \\
\text { employees in category B jobs for bigger firms * }\end{array}$ & 0.0013 & 0.0011 \\
\hline $\begin{array}{l}\text { Total non-unionised employees in category B jobs > } 20 \% \text { of total } \\
\text { employees in category B jobs for smaller firms * }\end{array}$ & 0.00074 & 0.00065 \\
\hline $\begin{array}{l}\text { Total non-unionised employees in category B jobs participation } \\
\text { in formalised committees for bigger firms * }\end{array}$ & 0.012 & 0.0094 \\
\hline $\begin{array}{l}\text { Total non-unionised employees in category B jobs participation } \\
\text { in formalised committees for smaller firms * }\end{array}$ & 0.0011 & 0.00085 \\
\hline $\begin{array}{l}\text { Total non-unionised employees in category B jobs participation } \\
\text { in non-committee based platforms for bigger firms * }\end{array}$ & 0.00093 & 0.00091 \\
\hline $\begin{array}{l}\text { Total non-unionised employees in category B jobs participation } \\
\text { in non-committee based platforms for smaller firms * }\end{array}$ & 0.00061 & 0.00051 \\
\hline Less than $50 \%$ family-owned $* \star$ & 0.69 & 0.65 \\
\hline More than $50 \%$ family-owned $* *$ & 0.31 & 0.35 \\
\hline$\%$ of total sales in domestic market for bigger firms $\star \star$ & 0.74 & 0.87 \\
\hline$\%$ of total sales in domestic market for smaller firms *夫 & 0.91 & 0.93 \\
\hline $\begin{array}{l}\text { More than } 60 \% \text { share of one race group of non-unionised } \\
\text { employees in category B jobs for bigger firms } \star \star\end{array}$ & 0.73 & 0.79 \\
\hline
\end{tabular}




\begin{tabular}{|c|c|c|}
\hline Variable & Manufacturing & Construction \\
\hline $\begin{array}{l}\text { Less than } 60 \% \text { share of one race group of non-unionised } \\
\text { employees in category } B \text { jobs for bigger firms ** }\end{array}$ & 0.27 & 0.21 \\
\hline $\begin{array}{l}\text { More than } 60 \% \text { share of one race group of non-unionised } \\
\text { employees in category } B \text { jobs for smaller firms } \star \star\end{array}$ & 0.68 & 0.65 \\
\hline $\begin{array}{l}\text { Less than } 60 \% \text { share of one race group of non-unionised } \\
\text { employees in category B jobs for smaller firms } \star \star\end{array}$ & 0.32 & 0.35 \\
\hline $\begin{array}{l}\text { Less than } 25 \% \text { female participation of non-unionised employees } \\
\text { in category } B \text { jobs for bigger firms *夫 }\end{array}$ & 0.59 & 0.73 \\
\hline $\begin{array}{l}\text { Less than } 25 \% \text { female participation of non-unionised employees } \\
\text { in category B jobs for smaller firms ** }\end{array}$ & 0.61 & 0.68 \\
\hline $\begin{array}{l}\text { More than } 25 \% \text { female participation of non-unionised employees } \\
\text { in category } B \text { jobs for bigger firms ** }\end{array}$ & 0.41 & 0.37 \\
\hline $\begin{array}{l}\text { More than } 25 \% \text { female participation of non-unionised employees } \\
\text { in category B jobs for smaller firms ** }\end{array}$ & 0.39 & 0.32 \\
\hline $\begin{array}{l}\text { Non-unionised employees in category } B \text { jobs younger than } 35 \\
\text { years of age - bigger firms } \star \star\end{array}$ & 0.27 & 0.19 \\
\hline $\begin{array}{l}\text { Non-unionised employees in category } B \text { jobs younger than } 35 \\
\text { years of age - smaller firms } \star \star\end{array}$ & 0.21 & 0.15 \\
\hline $\begin{array}{l}\text { Non-unionised employees in category } B \text { jobs between } 35 \text { and } 55 \\
\text { years of age - bigger firms } \star \star\end{array}$ & 0.48 & 0.53 \\
\hline $\begin{array}{l}\text { Non-unionised employees in category B jobs between } 35 \text { and } 55 \\
\text { years of age - smaller firms } \star \star\end{array}$ & 0.58 & 0.61 \\
\hline $\begin{array}{l}\text { Non-unionised employees in category } B \text { jobs older than } 55 \text { years } \\
\text { of age-bigger firms } * \star\end{array}$ & 0.25 & 0.28 \\
\hline $\begin{array}{l}\text { Non-unionised employees in category } B \text { jobs older than } 55 \text { years } \\
\text { of age-smaller firms ** }\end{array}$ & 0.21 & 0.23 \\
\hline
\end{tabular}

* Weighted average concentration ratios

$\star \star$ Percentage weights 